\title{
Induction of NF- $\kappa$ B Activity during Haloperidol-Induced Oxidative Toxicity in Clonal Hippocampal Cells: Suppression of NF- $\kappa$ B and Neuroprotection by Antioxidants
}

\author{
Anke Post, Florian Holsboer, and Christian Behl \\ Max Planck Institute of Psychiatry, 80804 Munich, Germany
}

Haloperidol (HP), a dopamine receptor antagonist, is cytotoxic to mouse clonal hippocampal HT22 cells in a concentrationdependent manner and causes cell death by oxidative stress. The addition of HP to HT22 cells led to an increase in intracellular peroxides and a time-dependent drop in the intracellular glutathione levels. HP-induced oxidative cell death was prevented by the pineal hormone melatonin, its precursor $N$-acetyl serotonin, and most effectively by vitamin $\mathrm{E}$ ( $\alpha$-tocopherol). These antioxidants inhibited the intracellular peroxide accumulation and stabilized the glutathione content of HT22 cells after

Haloperidol (HP) is a widely used neuroleptic drug for the treatment of acute and chronic psychosis, e.g., schizophrenia. HP belongs to butyrophenones and is thought to exert its clinical effect through cerebral dopamine D2-receptors (Creese et al., 1976) and $\sigma$-receptors (Walker et al., 1990; Vilner and Bowen, 1993; Vilner et al., 1995). Use of neuroleptics, especially of butyrophenones, is limited by their tendency to produce a range of extrapyramidal movement disorders such as parkinsonism, akathisia, dystonia, and finally, chronic tardive dyskinesia (Marsden and Jenner, 1980). The latter syndrome has been causally related to neuroleptic-induced increase in free radical production resulting in degeneration of susceptible neurons (Cadet et al., 1986; Lohr et al., 1988).

Indeed, HP can be cytotoxic in vitro (Vilner and Bowen, 1993; Behl et al., 1995, 1996) and also in vivo (Bowen et al., 1990). Furthermore, HP administration resulted in a depletion of the antioxidant glutathione (GSH) in various regions of the brain in rodents (Shivakumar and Ravindranath, 1992, 1993) as well as in the CSF of HP-treated patients where this GSH depletion was also associated with an enhanced lipid peroxidation (Pai et al., 1994). GSH plays multiple roles in cells during DNA synthesis and repair, protein synthesis, and enzyme activation, and as a free radical scavenger (Meister, 1991). In addition to their direct damaging effect, reactive oxygen species can induce the activation and expression of certain transcriptional factors and genes (Meyer et al., 1993; Schenk et al., 1994; Schieven et al., 1994; Staal et al., 1994; Brennan and O’Neill, 1995; Pinkus et al., 1996).

The nuclear transcription factor NF- $\kappa \mathrm{B}$ was the first eukaryotic

Received May 15, 1998; revised July 23, 1998; accepted Aug. 6, 1998.

We thank S. Engert, B. Berning, and S. Deindl for expert technical assistance. We are also grateful to Drs. F. Lezoualc'h and S. Heck for helpful comments on this manuscript and to Dr. M. Engelmann for help in the statistical evaluation of the data.

Correspondence should be addressed to Dr. Christian Behl, Max Planck Institute of Psychiatry, Kraepelinstrasse 2-16, 80804 Munich, Germany.

Copyright (C) 1998 Society for Neuroscience $\quad 0270-6474 / 98 / 188236-10 \$ 05.00 / 0$ the challenge with HP. At the molecular level, HP specifically induced the DNA binding activity and the transcriptional activity of the redox-sensitive transcription factor NF- $\kappa \mathrm{B}$. This enhanced NF- $\kappa$ B activity could be blocked by the neuroprotective antioxidants. The specific suppression of NF- $\kappa \mathrm{B}$ by its inhibitor $I_{\kappa} \mathrm{B} \alpha$ partially protected the cells against HP, indicating that the activation of NF- $\kappa \mathrm{B}$ may be involved in HP-induced oxidative cell death in vitro.

Key words: haloperidol; oxidative stress; glutathione; NF-кB; melatonin; vitamin $E$

transcription factor to be shown to respond directly to oxidative stress (Schreck et al., 1991; Schmidt et al., 1995). NF- $\kappa$ B resembles a heterodimeric protein composed of a 50 and a $65 \mathrm{kDa}$ subunit (Sen and Baltimore, 1986). Typically, NF- $\kappa$ B is sequestered in the cytoplasm by the specific inhibitory protein $\mathrm{I} \kappa \mathrm{B}$, which tightly controls NF- $\kappa$ B's activation and regulation (Baldwin, 1996).

Indirect support for a possible involvement of oxidative stress in HP toxicity is provided by studies that showed that the lipophilic free radical scavenger vitamin E prevents HP-induced cell death in vitro (Behl et al., 1995) and has beneficial effects in patients with tardive dyskinesia (Lohr et al., 1988; Egan et al., 1992; Lohr and Caligiuri, 1996).

The goal of this study was to further elucidate the molecular pathways that lead to the oxidative neurotoxicity of HP using the clonal mouse hippocampal cell line HT22. Here, an HP-induced drop in the GSH level and a subsequent rise in intracellular peroxides was found. Moreover, for the first time it is shown that the activation of the nuclear transcription factor $\mathrm{NF}-\kappa \mathrm{B}$ is involved in the neurotoxicity of HP.

\section{MATERIALS AND METHODS}

Material. All media, sera, and media supplements were from Life Technologies (Eggenstein, Germany). Haloperidol and sulpiride were obtained from RBI Biochemicals (Biotrend, Köln, Germany), the 2',7'dichlorofluorescein diacetate (DCF-dA) was obtained from Molecular Probes (Eugene, OR), and the polyethylenimine (PEI) was obtained from Aldrich (Deisenhofen, Germany). Melatonin, $N$-acetyl-serotonin, and all other chemicals were purchased from Sigma (Deisenhofen, Germany) unless stated otherwise.

Cell culture and cytotoxicity assays. The HT22 cells were a kind gift from Dr. P. Maher (The Scripps Research Institute, La Jolla, CA) and were cultured in DMEM supplemented with $10 \%$ fetal calf serum (FCS) under standard culture conditions as described (Maher and Davis, 1996).

To assess cell viability, a modified 3-(4,5-dimethylthiazol-2-yl)-2,5 diphenyl tetrazolium bromide (MTT) assay was performed as described (Behl et al., 1994). Briefly, 3000-5000 HT22 cells were plated in 96-well 
microtiter dishes with $100 \mu \mathrm{l}$ per well. After $20 \mathrm{hr}$ of HP challenge, the MTT assay was performed. To investigate the protective effect of antioxidants, $N$-acetyl-serotonin and melatonin were added to the cells for 20 $\mathrm{hr}$, whereas vitamin E was added $6 \mathrm{hr}$ before the challenge with HP. To circumvent the possibility that these antioxidants potentially might interfere with the colorimetric MTT assay, the trypan blue exclusion assay was performed in combination with cell counting using morphological criteria for cell death (Behl et al., 1994). In this assay, cells were plated in $60 \mathrm{~mm}$ dishes and preincubated with antioxidants and HP at the same time points as for the MTT assays. Each survival assay was performed in triplicate and repeated at least three times. For cell counting, at least five optical fields with $>200$ cells were observed, and cellular survival was determined.

Transfection, luciferase assay, and plasmids. For transient transfection with $6 \times \mathrm{NF}-\kappa \mathrm{B}-$ tk-luciferase-, tk-luciferase control-, CMV-I $\kappa \mathrm{B} \alpha$ superrepressor-, and CMV-control vectors, HT22 cells were seeded at 50,000 cells per 24-well tissue culture dishes and transfected with PEI, as described previously (Boussif et al., 1995; Lezoualc'h et al., 1998a). PEI was used at 10 equivalents (10 amino groups per phosphate group; $0.3 \mu \mathrm{l}$ of $100 \mathrm{~mm}$ PEI per $1 \mu \mathrm{g}$ of plasmid). DNA ( $2 \mu \mathrm{g} /$ well) and PEI were first diluted in $150 \mathrm{~mm} \mathrm{NaCl}$. PEI/DNA complexes were obtained by gently mixing the two solutions; then, after $10 \mathrm{~min}$, the transfection solution mixture was diluted in $500 \mu \mathrm{l}$ of DMEM without serum and applied to the cells for $3 \mathrm{hr}$. The cells were rinsed and cultured with DMEM and supplemented with $10 \%$ fetal calf serum. Then, HP was applied to the cultures for various time periods at increasing concentrations (up to 100 $\mu \mathrm{M})$, pretreated or not pretreated with the antioxidants. Luciferase activity of cell extracts was monitored as reported previously (De Wet et al., 1987; Lezoualc'h et al., 1998b). Each transfection experiment was performed in triplicate using identical cell density and was repeated three times and controlled for equal amounts of protein using the Bio-Rad protein reagent to determine the concentrations of the protein samples (Bio-Rad, München, Germany). Identical transfection efficiencies in the various experiments were controlled by transfecting a tkluciferase control vector lacking the NF- $\kappa$ B-binding DNA consensus sites. As described previously, the transfection procedure itself did not interfere with the end result (Lezoualc'h et al., 1998b).

The NF- $\kappa$ B-Luc construct containing $6 \times$ NF- $\kappa$ B-binding DNA consensus sites linked to a luciferase reporter gene and the tk-Luc construct containing only the thymidine luciferase promoter linked to a luciferase construct were generously provided by Dr. P. Bäuerle (Tularik Inc., San Francisco, CA). The CMV-I $\kappa \mathrm{B} \alpha$ super-repressor and the CMV-control vector missing the $\mathrm{I} \kappa \mathrm{B} \alpha$ cDNA were kindly provided by Dr. D. W. Ballard (Vanderbilt University, Nashville, TN).

Detection of intracellular peroxides. Intracellular accumulation of $\mathrm{H}_{2} \mathrm{O}_{2}$ was determined by using DCF-dA (Behl et al., 1994). HT22 cells were plated and preincubated with antioxidants. Six hours after the addition of $\mathrm{HP}, 10 \mu \mathrm{M}$ DCF-dA was added for $1 \mathrm{hr}$ at $37^{\circ} \mathrm{C}$. Cells were then washed with phenol red-free HEPES-buffered DMEM, supplemented with $2 \%$ FCS, and the cultures were viewed with a fluorescence microscope using fluorescein optics. Fluorescence was determined qualitatively by counting the cells first under phase contrast and then under fluorescence conditions. For quantification, $>200$ cells per low-magnification field were counted in five separate experiments. Results are expressed as the percentage of fluorescent cells.

Total intracellular GSH and oxidized form of GSH determination. HT22 cells were seeded at $1 \times 10^{6}$ cells per $10 \mathrm{~mm}$ dish and treated for various times with HP and antioxidants. Subsequently, the cells were washed twice with ice-cold PBS, collected by scraping, and lysed with $3 \%$ sulfosalicylic acid. After incubation for $20 \mathrm{~min}$ on ice, supernatants were collected after centrifugation and neutralized with triethanolamine. Total GSH was determined according to Tietze (1969), modified by Griffith (1980) and Li et al. (1997). Pure GSH was used to obtain the standard curve.

Western blot analysis. For Western blot analysis, $10 \mathrm{~cm}$ dishes of HT22 cells $\left(1 \times 10^{6}\right)$ were treated with HP or left untreated. Thereafter, the cells were washed with PBS, and nuclear extracts were prepared as described (Schreiber et al., 1989). Extracts with equal amounts of protein were resolved on a $8 \%$ SDS-polyacrylamide gel, transferred onto a polyvinylidene difluoride transfer membrane (Amersham, Braunschweig, Germany), and then detected with an antibody against the NF- $\kappa$ B subunit p65 (Santa Cruz Biotechnology, Santa Cruz, CA) or against actin (Boehringer Mannheim, Mannheim, Germany) as a control for equal protein loading. The specific binding of the first antibody was detected by counterstaining with a horseradish peroxidase-linked antibody and visualized by the ECL-detection kit (Amersham).

Electrophoretic mobility shift assay. Nuclear extracts for the electrophoretic mobility shift assays (EMSAs) were prepared by a miniextraction protocol (Schreiber et al., 1989). Consensus sequences of NF- $\kappa$ B (5'-AGT TGA GGG GAC TTT CCC AGG C-3'), AP-1, and Oct-1 were used for gel shift assays (Promega/Serva, Heidelberg, Germany). Double-stranded oligonucleotides were end-labeled with $\gamma$-[ $\left.{ }^{32} \mathrm{P}\right]$ ATP $(3000 \mathrm{Ci} / \mathrm{mmol}$; Amersham) and T4 polynucleotide kinase (Promega/Serva) and purified on a G-25 column. Nuclear extracts (6-12 $\mu \mathrm{g})$ were incubated for $20 \mathrm{~min}$ at room temperature with $20 \mu \mathrm{l} \mathrm{of} 2 \mu \mathrm{g}$ of poly (dI-dC) (Pharmacia, Freiburg, Germany), 10\% glycerol, $100 \mathrm{~mm}$ $\mathrm{NaCl}, 1 \mathrm{~mm}$ EDTA, $1 \mathrm{~mm}$ dithiothreitol, $0.5 \mathrm{~mm}$ phenylmethylsulfonyl fluoride, and 15,000-25,000 counts per min of ${ }^{32} \mathrm{P}$-oligonucleotides. For reaction with specific antibodies, the nuclear extracts were incubated for $12 \mathrm{hr}$ at $4^{\circ} \mathrm{C}$ with $2 \mu \mathrm{l}$ of either p50 or p65 antibody stocks (Santa Cruz Biotechnologies) before addition of the labeled NF- $\kappa$ B. The specificity of the binding was determined by competition with an excess amount of unlabeled NF- $\kappa \mathrm{B}$, AP-1, or Oct-1 oligonucleotides. DNA-protein complexes were resolved on a $6 \%$ nondenaturing polyacrylamide gel at 20 $\mathrm{mA}$ for $3 \mathrm{hr}$ in $0.5 \times$ TBE (45 mM Tris-borate and $1 \mathrm{~mm}$ EDTA). Gels were vacuum-dried and exposed to Fuji x-ray films at $-80^{\circ} \mathrm{C}$ for $10-24 \mathrm{hr}$. The binding activities of NF- $\kappa \mathrm{B}, \mathrm{AP}-1$, and Oct- 1 were quantified by scanning the autoradiographies using a Beckmann photometer.

Statistical analysis. For statistical comparison, Kruskal-Wallis ANOVA followed by the Mann-Whitney $U$ test was used as indicated. $p$ values $<0.05$ were considered significant.

\section{RESULTS}

\section{Haloperidol is toxic to HT22 cells}

As shown in Table 1, the addition of HP to the cell culture medium reduced HT22 cell survival dose-dependently as reported for other cell lines and for rat primary cells (Vilner and Bowen, 1993; Behl et al., 1995, 1996). HP addition resulted in rapid morphological changes starting after $\sim 6 \mathrm{hr}$ and in complete cell death after treatment with $100 \mu \mathrm{M} \mathrm{HP}$ for $20 \mathrm{hr}$ (Fig. 1, Table 1). To quantify the cell viability, MTT assays as a sensitive first indicator of oxidative damage (Behl et al., 1994; Liu et al., 1997) and the trypan blue exclusion-cell counting methods were used. Although after incubation of HT22 cells with $50 \mu \mathrm{M} \mathrm{HP} \sim 40 \%$ of cells were still alive, addition of $100 \mu \mathrm{M}$ caused a complete cell lysis after $20 \mathrm{hr}$. At a concentration as low as $1 \mu \mathrm{M} \mathrm{HP}$, cell viability was already reduced by $\sim 20 \%$ (Table 1 ). In contrast, the D2-receptor antagonist sulpiride is not toxic to HT22 cells up to concentrations of $100 \mu \mathrm{M}$ as detected by the MTT assay and the trypan blue exclusion method (Table 2).

\section{Melatonin, its precursor $\mathbf{N}$-acetyl serotonin, and vitamin E protect HT22 cells against HP toxicity}

In addition to vitamin $\mathrm{E}$, the pineal hormone melatonin $(N$ acetyl-5-methoxytryptamine) and its precursor $N$-acetylserotonin are neuroprotective antioxidants (Melchiorri et al., 1995; Reiter et al., 1996; Lezoualc'h et al., 1996, 1998a).

Preincubation of the HT22 cells with melatonin, $N$-acetylserotonin, and vitamin E decreased HP-induced cell death (Table 1). $N$-acetyl-serotonin proved to be more effective in preventing HP toxicity than melatonin (Table 1 ). Although $1 \mathrm{~mm} N$-acetylserotonin increased the cell viability by $54 \pm 3 \%$ after a toxic challenge with $100 \mu \mathrm{M} \mathrm{HP}$, the same concentration of melatonin enhanced the viability by only $22 \pm 1 \%$ (Table 1 ). HT22 cells, preincubated with $200 \mu \mathrm{M}$ vitamin E, completely protected the 


\begin{tabular}{|c|c|c|c|c|}
\hline \multirow[b]{2}{*}{ Reagent } & \multirow{2}{*}{$\begin{array}{l}\text { Concentration } \\
(\mu \mathrm{M})\end{array}$} & \multicolumn{2}{|c|}{ Percent toxicity in HT22 cells } & \multirow{2}{*}{$\begin{array}{l}\text { Percent increase } \\
\text { of peroxides }\end{array}$} \\
\hline & & Viability & MTT reduction & \\
\hline Control & & 100 & 100 & $3.0 \pm 0.8^{a}$ \\
\hline Haloperidol & 1 & & $82.5 \pm 1.6^{b}$ & \\
\hline Haloperidol & 10 & $84 \pm 4.7^{c}$ & $82.5 \pm 6.8$ & \\
\hline Haloperidol & 50 & $39.9 \pm 4.4$ & $33.7 \pm 1.4$ & \\
\hline Haloperidol & 100 & $1.0 \pm 0.9$ & 0 & $36.7 \pm 0.5^{d}$ \\
\hline \multirow[t]{3}{*}{ Haloperidol $100 \mu \mathrm{M}$ plus $N$-acetyl serotonin } & 10 & $26.6 \pm 3.5$ & $5.1 \pm 0.8$ & \\
\hline & 100 & $33.8 \pm 4.7$ & $6.6 \pm 0.6$ & \\
\hline & 1000 & $54.4 \pm 2.9^{e}$ & $44.5 \pm 7.5^{f}$ & $11.3 \pm 1.2^{g}$ \\
\hline \multirow[t]{3}{*}{ Haloperidol $100 \mu \mathrm{M}$ plus melatonin } & 10 & $20.3 \pm 5.0$ & $5.8 \pm 1.5$ & \\
\hline & 100 & $25.7 \pm 6.1$ & $9.6 \pm 1.4^{h}$ & \\
\hline & 1000 & $22.5 \pm 1.1$ & $3.5 \pm 0.5$ & $25.6 \pm 0.5$ \\
\hline \multirow[t]{3}{*}{ Haloperidol $100 \mu \mathrm{M}$ plus $\alpha$-tocopherol } & 2 & $22.7 \pm 6.1$ & & \\
\hline & 20 & $67.2 \pm 2.0$ & & \\
\hline & 200 & $99.3 \pm 3.7^{i}$ & & $1.3 \pm 0.4^{j}$ \\
\hline
\end{tabular}

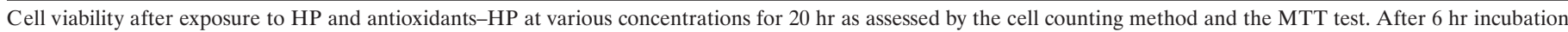

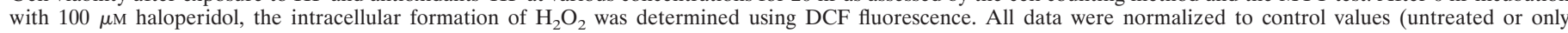

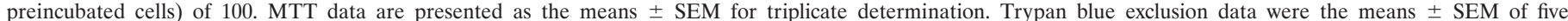

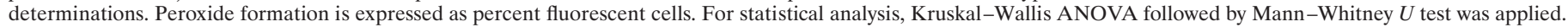
$a_{p}<0.025$ versus HP, NAS, and melatonin.

${ }^{b} p<0.025$ versus all treatment conditions.

${ }^{c} p<0.025$ versus all treatment conditions.

${ }^{d} p<0.025$ versus all other treatment conditions and control.

${ }^{e} p<0.05$ versus all other $N$-acetyl-serotonin (NAS) dosages.

${ }^{f} p<0.025$ versus all other NAS and versus $100 \mu \mathrm{M}$ melatonin.

${ }^{g} p<0.025$ versus melatonin.

${ }^{h} p>0.05$ versus all other melatonin dosages.

${ }^{i} p<0.01$ versus all other vitamin E dosages and versus $100 \mu \mathrm{M}$ NAS and $1000 \mu \mathrm{M}$ melatonin.

${ }^{j} p<0.05$ versus all others.

cells $(99 \pm 4 \%)$ against HP. In vitamin E-pretreated cultures, the morphology of the HT22 cells was completely unaffected by the HP challenge, reflecting the full protection afforded by this antioxidant (Fig. 1).

\section{HP causes intracellular peroxide accumulation in HT22 cells}

To investigate the role of oxidative stress as one possible mechanism of HP cytotoxicity, the intracellular peroxide levels of HT22 cells after HP treatment were determined by using DCF$\mathrm{dA}$. The addition of HP led to an increase in DCF-fluorescence after $6 \mathrm{hr}$, which was indicative of the accumulation of $\mathrm{H}_{2} \mathrm{O}_{2}$ and related peroxides. This increased fluorescence could be blocked by antioxidants. Consistent with the cell survival data, vitamin $\mathrm{E}$ most effectively blocked the intracellular accumulation of peroxides, as shown in Figure 1 and Table 1.

\section{HP affects the intracellular GSH level}

Intracellular GSH levels increased after HP addition to the HT22 cells in the first few hours, followed by a dramatic decrease after 16-20 hr (Fig. 2A). As shown in Figure 2B, antioxidant addition increased the GSH level after challenge with $100 \mu \mathrm{M}$ HP. The preincubation with $1 \mathrm{~mm} \mathrm{~N}$-acetyl-serotonin increased the GSH level by $\sim 50 \%$, whereas melatonin did not lead to a significant rise. Vitamin E was again most effective in maintaining the GSH level at $90 \%$ of control cells, despite HP treatment.

\section{HP increases the transcriptional activity and DNA binding activity of NF- $\kappa$ B in HT22 cells}

After transient transfection with a NF- $\kappa \mathrm{B}$ reporter plasmid (NF$\kappa \mathrm{B}$-Luc), we found that HP treatment led to an activation of the $\kappa \mathrm{B}$-dependent reporter transcription construct in HT22 cells (Fig. $3 A)$. Although lower concentrations of HP (1 and $10 \mu \mathrm{M})$ led to a 3.4- to 3.6-fold increase in the transcriptional activity of NF- $\kappa \mathrm{B}$ after $2 \mathrm{hr}$, a higher concentration of HP $(50 \mu \mathrm{M})$ also increased the luciferase activity approximately fourfold as early as after 30 min. In Figure $3 C$, the transcriptional activities of NF- $\kappa \mathrm{B}$ after exposure to HP $(50 \mu \mathrm{M})$ for various time points are shown. In these experiments a lower HP concentration of $50 \mu \mathrm{M}$ was used because of the toxic effect of $100 \mu \mathrm{M} \mathrm{HP}$ after $2 \mathrm{hr}$. The transfection procedure is an additional stressor and renders the HT22 cells more vulnerable to HP. Post hoc microscopic investigations revealed a high level of damaged cells after incubation with 100 $\mu \mathrm{M}$ HP, which can explain the decrease in the luciferase activity. The transcription of the tk-Luc control plasmid was not altered after addition of HP (Fig. $3 B, D$ ) at any concentration or time point. Consistent with these data, the DNA binding activity of $\mathrm{NF}-\kappa \mathrm{B}$ was also increased after HP incubation for $2 \mathrm{hr}$. The DNA 


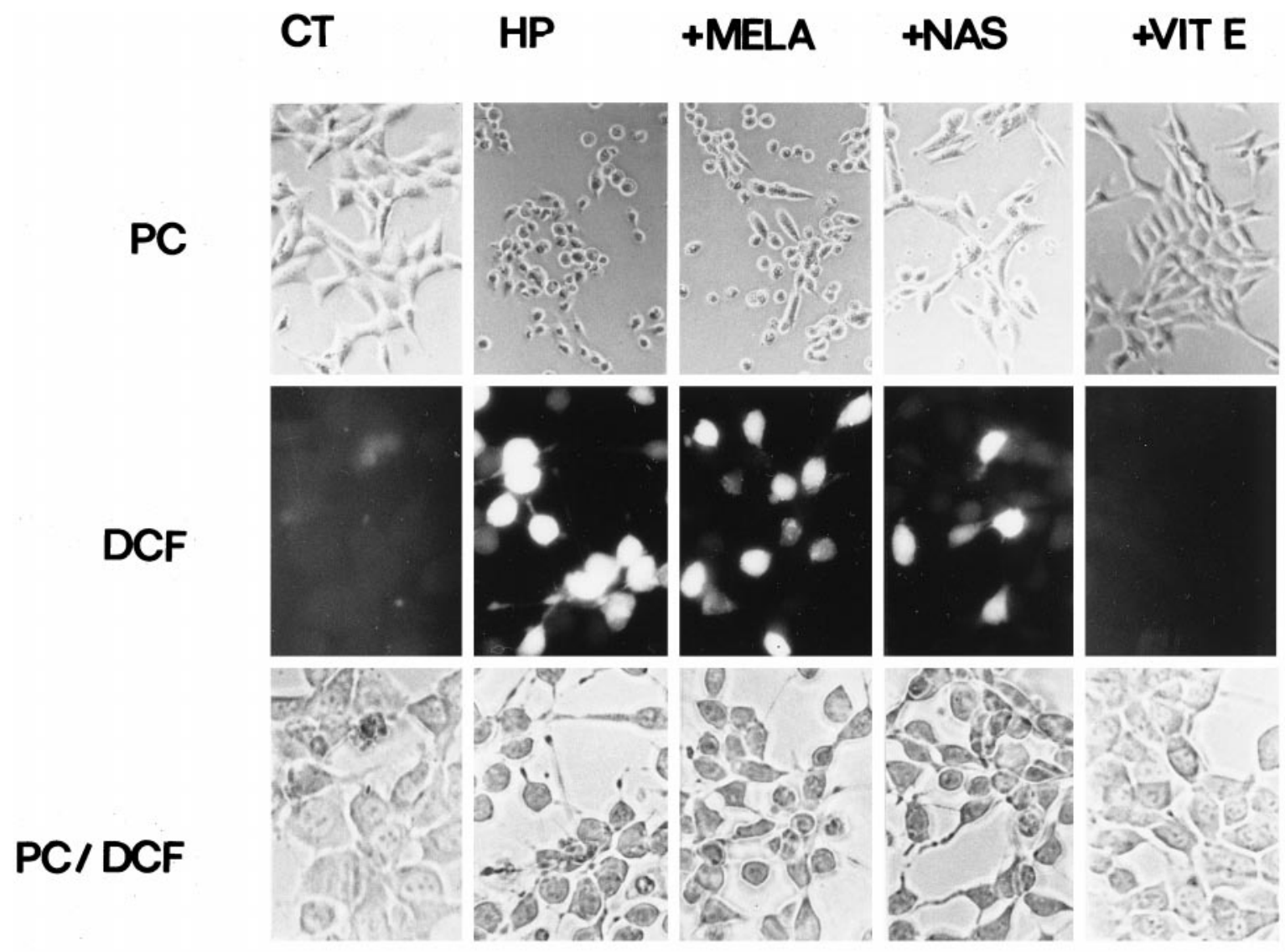

Figure 1. Vitamin E (VIT E), melatonin $(M E L A)$ and $N$-acetyl-serotonin $(N A S)$ prevent $\mathrm{HP}$-induced intracellular accumulation of $\mathrm{H}_{2} \mathrm{O}_{2}$ and, ultimately, cell death in clonal hippocampal HT22 cells. HT22 cells $\left(0.5 \times 10^{6}\right)$ were plated in $60 \mathrm{~mm}$ dishes and either pretreated with 1 mM melatonin, $1 \mathrm{~mm} N$-acetyl serotonin, and $200 \mu \mathrm{M}$ vitamin E or left untreated $(C T)$. Then, cells were incubated with $100 \mu \mathrm{M}$ HP for $20 \mathrm{hr}$ (survival assays) or 6 hr (peroxide staining). Cells are challenged with $100 \mu \mathrm{m}$ haloperidol for $20 \mathrm{hr}$. Cultures were first photographed under phase contrast $(P C)$, and then trypan blue exclusion method was performed in a parallel experiment. HP $(100 \mu \mathrm{M})$ was added for $6 \mathrm{hr}$, and intracellular peroxide formation was determined using DCF staining, as described in Materials and Methods. PC magnification, 100×; PC/DCF magnification, 200×.

\begin{tabular}{lcc}
\hline \multicolumn{2}{l}{ Table 2. Effect of sulpiride on cell viability } \\
Concentration $(\mu \mathrm{M})$ & Viability & MTT \\
\hline 1 & $103.7 \pm 5.0$ & $101.7 \pm 4.5$ \\
5 & $101.8 \pm 3.2$ & $116.2 \pm 3.4$ \\
10 & $108.2 \pm 1.6$ & $128.5 \pm 5.9$ \\
20 & $107.3 \pm 1.3$ & $107.4 \pm 10.4$ \\
50 & $101.6 \pm 9.3$ & $108.2 \pm 6.4$ \\
100 & $99.7 \pm 4.8$ & $110.4 \pm 3.9$ \\
200 & $80.0 \pm 14.4$ & $77.3 \pm 4.2$
\end{tabular}

The indicated concentrations of sulpiride were added to HT22 cells. After $24 \mathrm{hr}$, cell viability was determined by trypan blue exclusion method and cell counting. In a parallel experiment, MTT reduction was measured. All data were normalized to control values of 100 . Trypan blue exclusion data were the means \pm SEM of five determinations. MTT data are presented as the means \pm SEM for quadruplicate determination. A $p<0.025$ versus all other treatment conditions could be found only at a concentration of $200 \mu \mathrm{m}$ sulpiride.

binding activity of NF- $\kappa \mathrm{B}$ was increased approximately sixfold after treatment with $100 \mu \mathrm{M}$ HP (see Fig. 6A) compared with control cells. Although the DNA binding activity of NF- $\kappa \mathrm{B}$ was increased by HP, the DNA binding activity of AP-1, another redox-sensitive transcription factor, and Oct-1, an octameric transcription factor as control, was not significantly changed after HP addition (see Fig. 6A), indicating that there is not a general upregulation of transcription factors in HT22 cells induced by HP.

To identify the proteins involved in binding the labeled oligonucleotides in our EMSAs, nuclear extracts were incubated with antibodies against the p50 or the p65 subunit of NF- $\kappa$ B. The p50 antibody induced a supershift and the p65 antibody decreased the intensity of the specific band in the EMSA, indicating the involvement of both proteins in the DNA binding activity of NF- $\kappa \mathrm{B}$ in HT22 cells (see Fig. 6B).

\section{The nuclear expression of the NF- $\kappa$ B subunit p65 is increased in HT22 cells after HP addition}

To show whether the increased DNA binding and transcriptional activity of $\mathrm{NF}-\kappa \mathrm{B}$ is attributable to an increase of $\mathrm{NF}-\kappa \mathrm{B}$ protein levels, Western blot analysis of nuclear extracts was performed (Fig. 4). With an increased DNA binding and transcriptional activity of NF- $\kappa \mathrm{B}$ on HP treatment, HP consistently also caused an increased expression of the p65 subunit in the nuclear HT22 extracts (Fig. 4). 
A

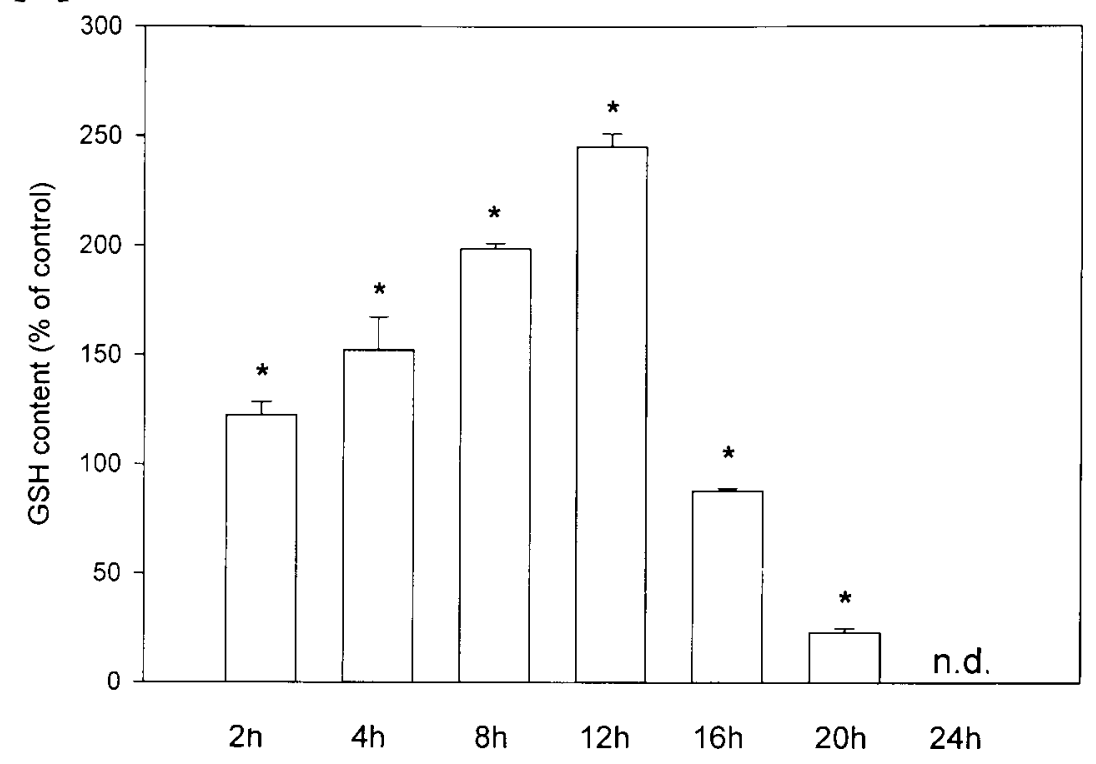

Figure 2. $A, \mathrm{HP}$ affects the level of intracellular GSH level in HT22 cells. HT22 cells $\left(1 \times 10^{6}\right)$ were incubated with $100 \mu \mathrm{M} \mathrm{HP}$, and the cells were harvested at the end of the indicated time. The level of total GSH $(\mathrm{nmol} / \mathrm{mg}$ protein) was determined as described in Materials and Methods and expressed as $100 \%$ GSH (nmol/mg protein) relative to the corresponding control level (n.d., nondetectable) $\left({ }^{*} p<0.05\right.$ vs all others). $B$, Preincubation with antioxidants $1 \mathrm{~mm} N$-acetyl-serotonin (NAS) and $200 \mu \mathrm{M}$ vitamin $\mathrm{E}$ and challenge with $100 \mu \mathrm{M} \mathrm{HP}$ for $16 \mathrm{hr}$ (1, control; 2, $100 \mu \mathrm{M} \mathrm{HP} ; 3,1 \mathrm{~mm}$ melatonin + $100 \mu \mathrm{M}$ HP; 4, 1 mM NAS + $100 \mu \mathrm{M} \mathrm{HP;} 5200 \mu \mathrm{M}$ vitamin $\mathrm{E}+100 \mu \mathrm{M} \mathrm{HP}) .{ }^{*} p<0.05$ versus control; ${ }^{*} p<$ 0.05 versus HP. All data are representative for one typical set of experiments. The SEM between the independent measurements is \pm 20 .

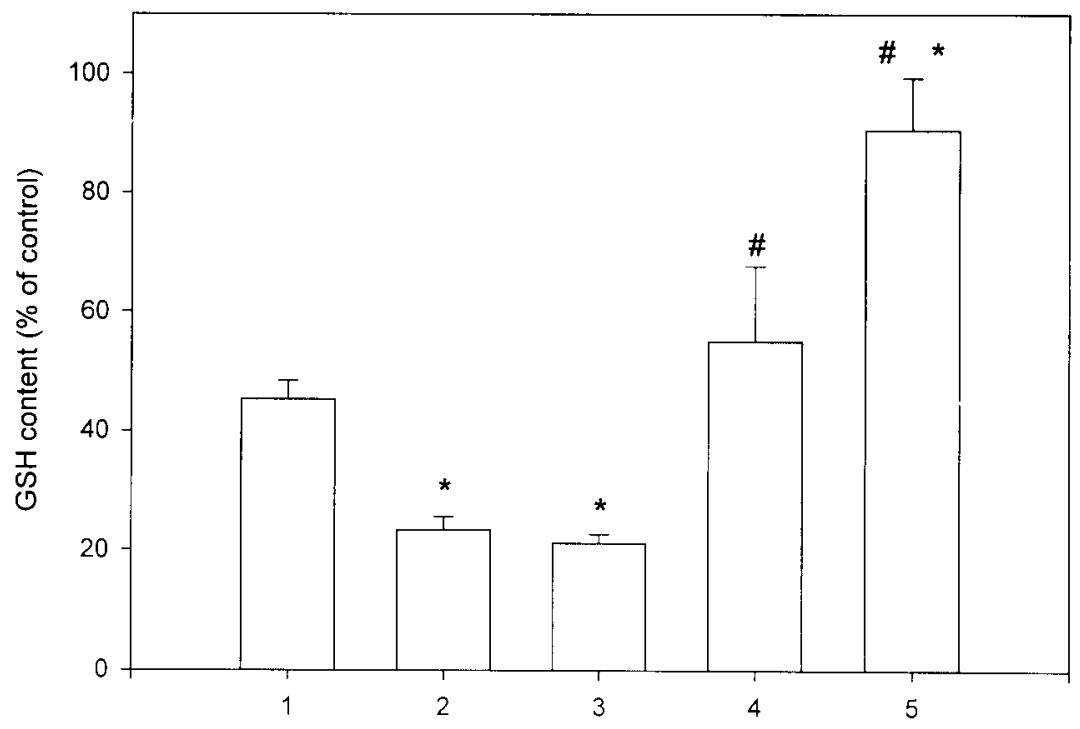

$\mathrm{N}$-acetyl serotonin and vitamin E suppress the HPinduced transcriptional activity and DNA binding activity of NF- $\kappa \mathrm{B}$

In HT22 cells preincubated with the neuroprotective antioxidants $N$-acetyl serotonin $(1 \mathrm{mM})$ and vitamin E $(200 \mu \mathrm{M})$, the HPinduced increase in the transcriptional activity of $\mathrm{NF}-\kappa \mathrm{B}$ was prevented (Fig. 5). The transcription of the tk-Luc vector was not altered by preincubation with $\mathrm{N}$-acetyl-serotonin or with vitamin $\mathrm{E}$ (data not shown). We then investigated the effect of $N$-acetyl serotonin and vitamin E on the HP-induced increase of NF- $\kappa$ B's binding activity. Although after preincubation with $N$-acetyl serotonin the HP-induced increase in the DNA binding activity of $\mathrm{NF}-\kappa \mathrm{B}$ was partially blocked, the pretreatment with vitamin $\mathrm{E}$ completely inhibited this increase (Fig. 6C). Consistent with the cell survival data, showing relatively poor neuroprotective action of melatonin against HP toxicity, this hormone only marginally decreased the HP-induced activation of $\mathrm{NF}-\kappa \mathrm{B}$ binding and transcriptional activity in these present assays (data not shown). 
A

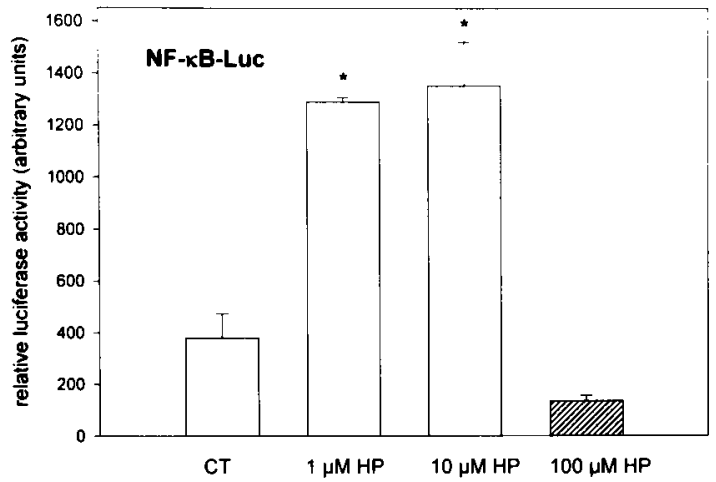

B

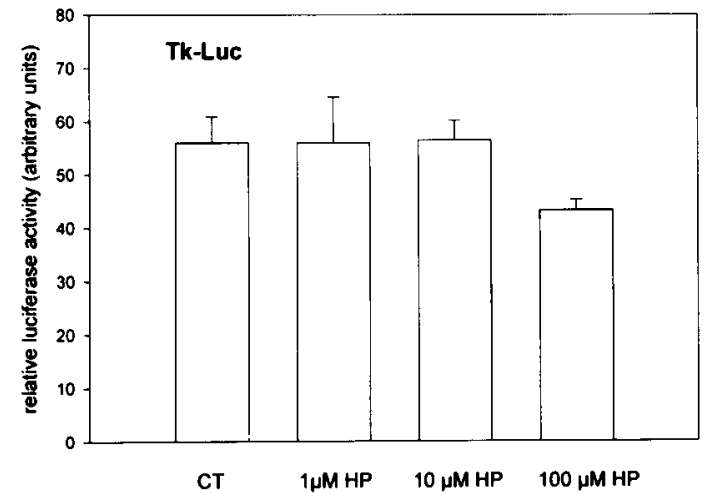

C

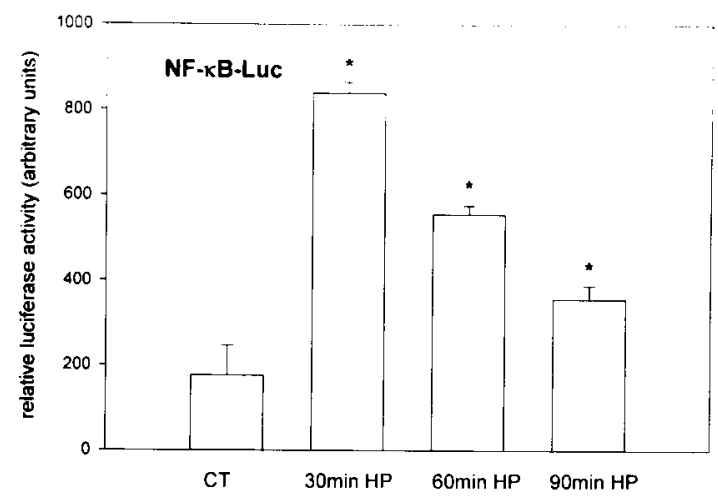

D

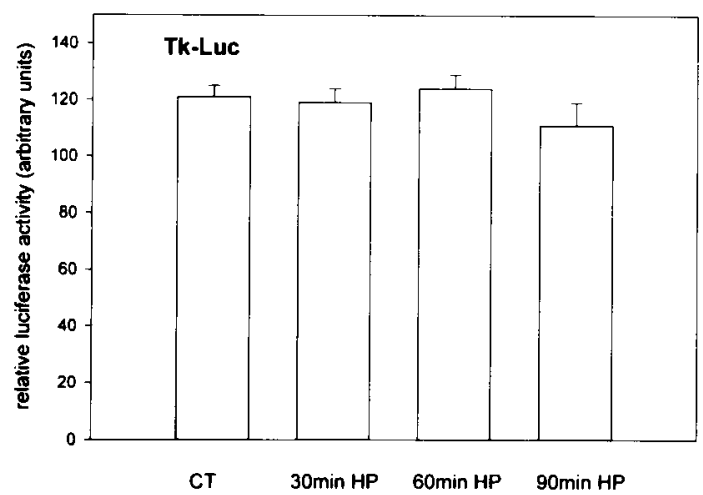

Figure 3. Transcriptional activity of NF- $\kappa$ B in HT22 cells. $A$, Cells were transfected with $2 \mu \mathrm{g}$ of NF- $\kappa \mathrm{B}$ Luc plasmid or Tk-Luc control plasmid (B) and then exposed to indicated concentrations of HP for $2 \mathrm{hr}$ or left untreated $(C T)$. $C$, Cells were transfected with $2 \mu \mathrm{g}$ of the NF- $\kappa \mathrm{B}$ plasmid or Tk-Luc control vector $(D)$ and then exposed to $50 \mu \mathrm{M}$ HP for the indicated times. Results are shown in arbitrary units of luciferase activity (relative luciferase activity) and are representative of three independent experiments. Hatched bars indicate that post hoc microscopic investigations revealed cell death. ${ }^{*} p<$ 0.025 versus all other HP concentrations or control.

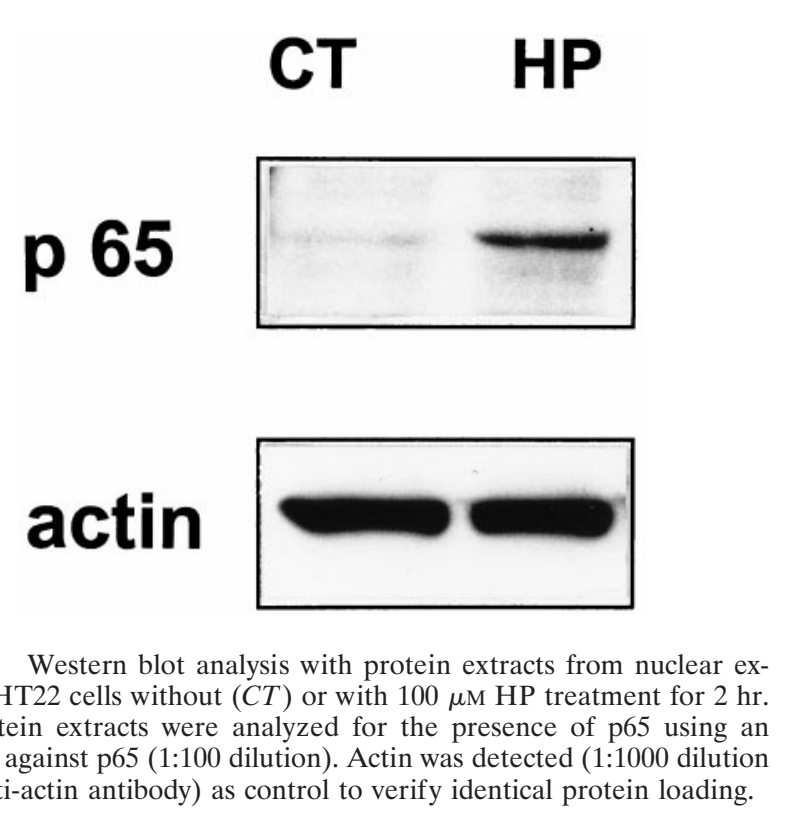

Figure 4. Western blot analysis with protein extracts from nuclear extract of HT22 cells without $(C T)$ or with $100 \mu \mathrm{M}$ HP treatment for $2 \mathrm{hr}$. The protein extracts were analyzed for the presence of p65 using an antibody against p65 (1:100 dilution). Actin was detected (1:1000 dilution
of an anti-actin antibody) as control to verify identical protein loading.
The overexpression of $I_{\kappa} \mathrm{B} \alpha$ suppresses the NF- $\kappa \mathrm{B}-$ dependent transcriptional activity and protects HT22 cells against HP

The transfection of cells with a super-repressor form of $\mathrm{I} \kappa \mathrm{B} \alpha$ that is resistant to both phosphorylation and proteolytic degradation of $\mathrm{I} \kappa \mathrm{B} \alpha$ prevents the nuclear translocation of NF- $\kappa \mathrm{B}$ (Brockman et al., 1995; Lezoualc'h et al., 1998b). After transfection of HT22 cells with the $\mathrm{I} \kappa \mathrm{B} \alpha$ super-repressor, the transcriptional baseline activity of NF- $\kappa \mathrm{B}$ was reduced by $\sim 56 \%$ compared with cells transfected with a CMV-control vector (Fig. $7 A$ ). In a parallel experiment, transfected HT22 cells were challenged with $10 \mu \mathrm{M}$ $\mathrm{HP}$ for $2 \mathrm{hr}$. The suppression of NF- $\kappa \mathrm{B}$ activity by $\mathrm{I} \kappa \mathrm{B} \alpha$ led to a partial protection of the HT22 cells against HP because the cell survival rate was significantly higher in the $\mathrm{I} \kappa \mathrm{B} \alpha$-overexpressing cells compared with the control-transfected cells (Fig. 7B).

\section{DISCUSSION}

In the present study, we found that HP concentrations between 1 and $100 \mu \mathrm{M}$ had effect on the morphology and ultimately the viability of mouse monoclonal hippocampal HT22 cells, a neuronal cell system that is frequently used to study oxidative cell death (Lezoualc'h et al., 1996; Maher and Davis, 1996; Li et al., 1997). 
Figure 5. $\quad N$-acetyl-serotonin (NAS) and vitamin $\mathrm{E}$ suppress the transcriptional activity of NF- $\kappa$ B. HT22 cells were transfected with $2 \mu \mathrm{g}$ of $\mathrm{NF}-\kappa \mathrm{B}$ Luc and preincubated with 1 mM NAS or $200 \mu \mathrm{M}$ Vitamin E or left untreated $(C T)$. Furthermore, cells were incubated with different concentrations of HP for $2 \mathrm{hr} .{ }^{*} p<$ 0.025 versus all other HP concentrations. Hatched bars indicate that post hoc microscopical investigations revealed cell death.

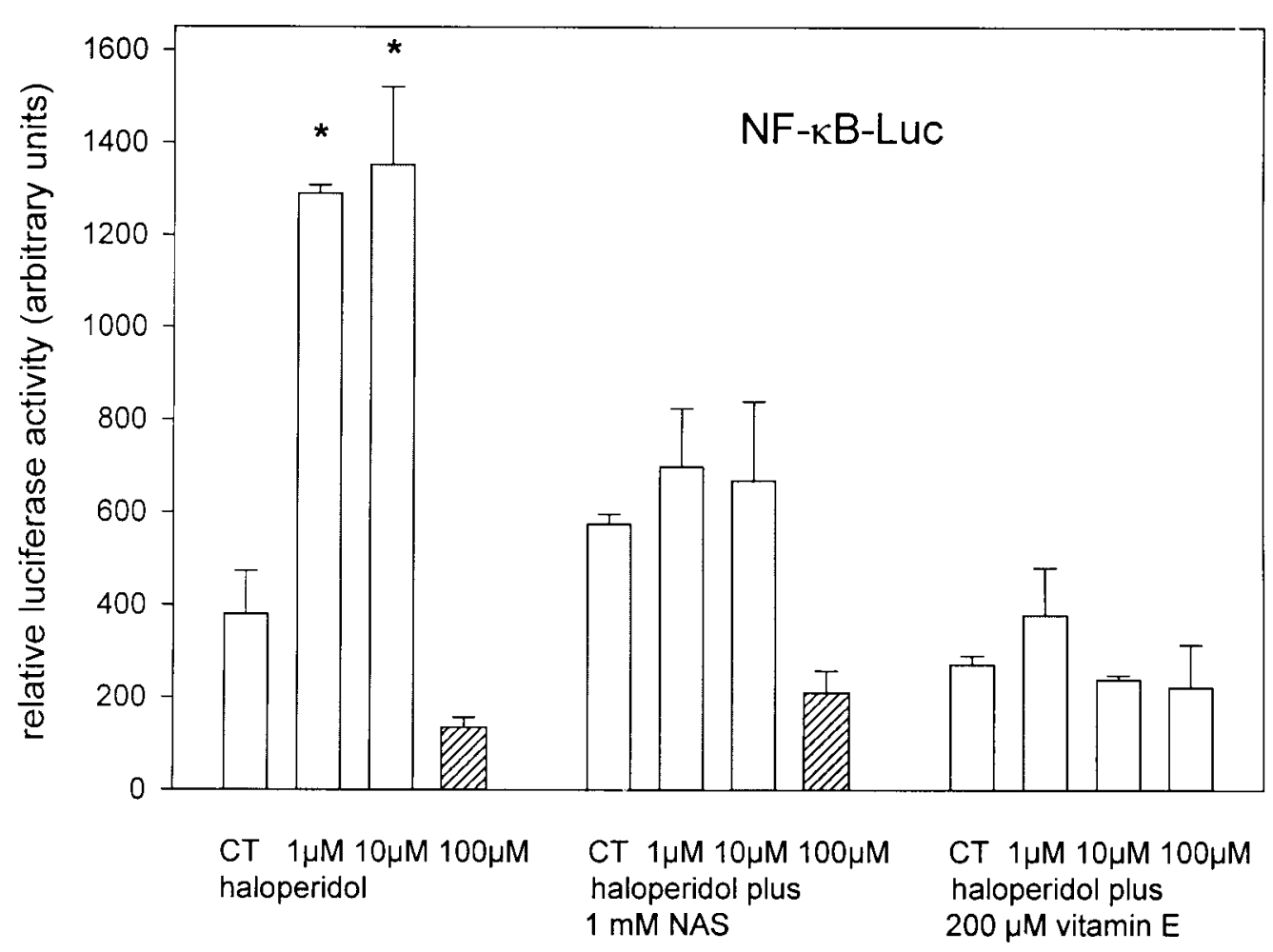

HP toxicity is associated with an increase in intracellular peroxides and a subsequent drop in GSH levels, which directly demonstrates the involvement of oxidative stress. HP caused the induction of the DNA binding and transcriptional activity of NF- $\kappa \mathrm{B}$, which could be blocked by $N$-acetyl-serotonin and vitamin E, two antioxidants that effectively prevent HP toxicity in HT22 cells at concentrations that have been demonstrated to prevent cell death by other oxidative challenges such as $\mathrm{H}_{2} \mathrm{O}_{2}$, amyloid $\beta$ protein, and glutamate (Behl et al., 1994; Moosmann et al., 1997). Moreover, suppression of NF- $\kappa \mathrm{B}$ activity by overexpression of its inhibitor $\mathrm{I} \kappa \mathrm{B} \alpha$ partially protected HT22 cells against HP toxicity. This effect of HP is probably not related to its dopamine D2-receptor antagonism, because sulpiride, another structurally different D2-receptor antagonist, was not toxic to HT22 cells at concentrations up to $100 \mu \mathrm{M}$.

Treatment of HT22 cells with HP generates elevated intracellular levels of $\mathrm{H}_{2} \mathrm{O}_{2}$ and related peroxides, suggesting that HP generates oxidative stress in this cellular system. Oxidative stress as induced by reactive oxygen species, such as $\mathrm{H}_{2} \mathrm{O}_{2}$, can damage cells by lipid peroxidation and can cause alterations of the structure of proteins and nucleic acids.

Cellular defenses against free radicals and reactive oxygen species include enzymatic and nonenzymatic mechanisms. The enzymatic defense consists mainly of catalase, GSH peroxidase, and superoxide dismutase; the nonenzymatic antioxidant mechanisms include ascorbic acid, vitamin E, and GSH (Halliwell and Gutteridge, 1989). The ability of GSH, a tripeptide composed of L-glutamate, L-cysteine, and glycine, to nonenzymatically scavenge both single oxygen and hydroxyl radicals provides the first line of antioxidant defense (Coyle and Puttfarcken, 1993; Bains and Shaw, 1997). Because there is increased peroxide generation after the HP challenge, intracellular GSH levels may be affected. The above data do indeed show a decrease in total intracellular
GSH levels after HP treatment. Under normal conditions, a sufficient amount of GSH is present maintaining a redox state that allows prevention of cell death through oxidative stress. Ultimately, HP addition led to a GSH depletion in HT22 cells after $16 \mathrm{hr}$. It is known that acute depletion of intracellular glutathione can cause cellular damage (Martensson et al., 1989; Meister, 1991), and moreover, alterations in glutathione status may be involved in neurodegenerative disorders such as Parkinson's disease and Alzheimer's disease (Olanow, 1992, 1993; Bains and Shaw, 1997). Our in vitro data are also consistent with reports of reduced GSH levels in HP-treated patients (Pai et al., 1994). The transient increase in total GSH caused by HP shown here comprises the reduced and the oxidized forms of GSH (GSSG); the latter is likely to be transiently increased in response to HPelicited peroxide formation. This transient increase of GSSG may probably trigger the activation of $\mathrm{NF}-\kappa \mathrm{B}$ activity after HP addition. Recent studies have consistently shown that an intact GSH system is required for an optimal induction of NF- $\kappa$ B by $\mathrm{H}_{2} \mathrm{O}_{2}$ because any depletion suppresses the NF- $\kappa \mathrm{B}$ response in Jurkat $\mathrm{T}$ cells (Ginn-Pease and Whisler, 1996). Furthermore, the activation of NF- $\kappa \mathrm{B}$ by oxidative stress is dependent on the GSH/ GSSG ratio and also on certain GSSG levels in lymphocytes (Dröge et al., 1995; Mihm et al., 1995). The current data support the hypothesis that similar mechanisms are also involved in neuronal cell systems.

$\mathrm{NF}-\kappa \mathrm{B}$ is a redox-sensitive transcription factor that can influence the neuronal sensitivity, suggesting that this factor has a potential role in neuroprotection (Lipton, 1997; Lezoualc'h and Behl, 1998). HP induces the transcriptional activity of NF- $\kappa \mathrm{B}$ and also its DNA binding activity in HT22 cells. Numerous stimuli, including neurotoxins such as amyloid $\beta$ protein and glutamate, activate this transcription factor (Grilli et al., 1993; Bäuerle and 


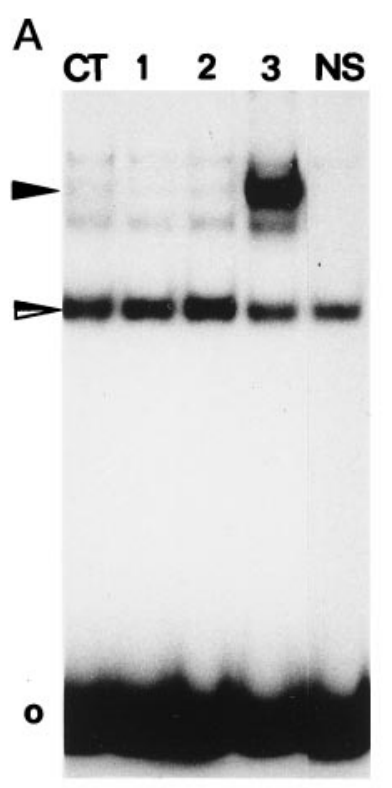

NF-kB

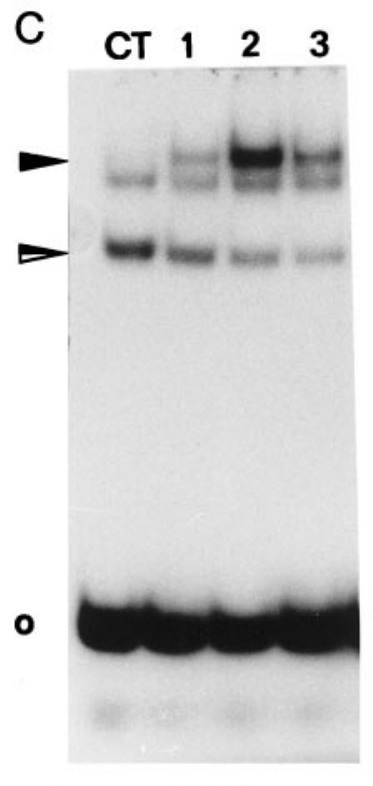

NAS
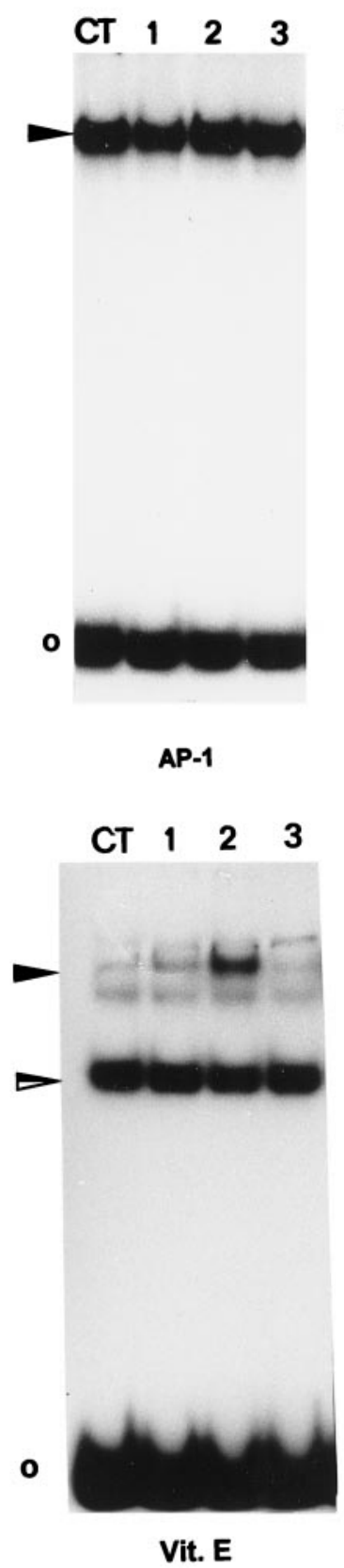

Henkel, 1994; Behl et al., 1994; Kaltschmidt et al., 1997; Lezoualc'h et al., 1998a).

It has been shown recently that melatonin and its precursor $\mathrm{N}$-acetyl-serotonin protect neurons against oxidative stress induced by $\mathrm{H}_{2} \mathrm{O}_{2}$ and glutamate (Lezoualc'h et al., 1996, 1998a; Reiter et al., 1996; Papolla et al., 1997). The neuroprotective effect of these hormones during HP treatment is consistent with their ability to decrease the induction of NF- $\kappa \mathrm{B}$ activity. Interestingly, it has been proposed that aspirin and sodium salicylate mediate neuroprotection also by a specific inhibition of glutamate-mediated induction of NF- $\kappa \mathrm{B}$ activity (Grilli et al., 1996). Although in the present experiments it appears that a block of NF- $\kappa \mathrm{B}$ activity is associated with neuroprotection, a different role of NF- $\kappa \mathrm{B}$ activity was found recently in another experimental paradigm. There it was shown that constitutively

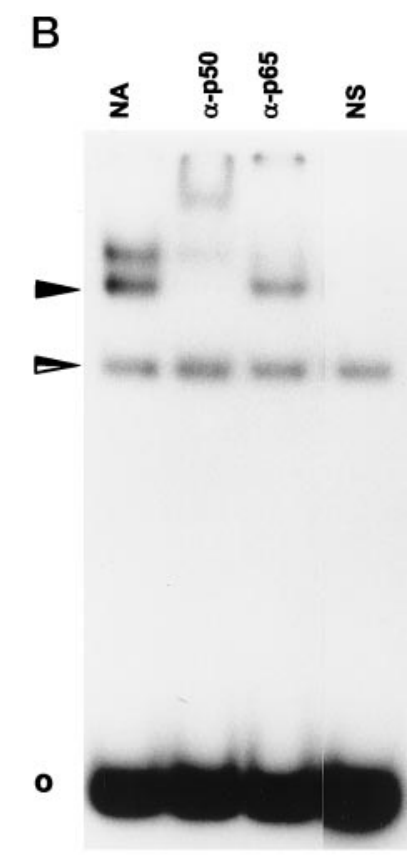

Figure 6. $A$, DNA binding activities of NF- $\kappa \mathrm{B}, \mathrm{AP}-1$, and Oct- 1 in HT22 cells are analyzed after HP addition with different concentrations. Nuclear extracts were prepared and EMSAs were performed. Autoradiograph of native gel is shown (lane 1,1 $1 \mathrm{M} \mathrm{HP}$; lane 2, $10 \mu \mathrm{M}$ HP; lane 3, $100 \mu \mathrm{M} \mathrm{HP).} \mathrm{B,} \mathrm{Nuclear} \mathrm{extracts} \mathrm{were} \mathrm{analyzed} \mathrm{after}$ reaction with an antibody against p65 or p50. $C$, DNA binding activity of NF- $\kappa \mathrm{B}$ in HT22 cells. The effect of HP-antioxidants on NF- $\kappa \mathrm{B}$ binding activity is depicted. Nuclear extracts were analyzed after challenges with $150 \mu \mathrm{M}$ hydrogen peroxide (lane 1) or $100 \mu \mathrm{M} \mathrm{HP}$ (lane 2) and after preincubation with $1 \mathrm{mM} N$-acetyl-serotonin/200 $\mu \mathrm{M}$ vitamin E (lane 3) and the following HP challenge with $100 \mu \mathrm{M}$ haloperidol for $2 \mathrm{hr}$. NS means nonspecific and represents the reaction mixture containing 100 -fold excess unlabeled NF- $\kappa$ B oligonucleotides as competitor. $N A$ means the control extract without an antibody. Filled arrowheads indicate the position of specific NF- $\kappa \mathrm{B} / \mathrm{DNA}$ complexes, half-filled arrowheads show the position of nonspecific complexes, and circles depict the position of the free DNA probe.

increased NF- $\kappa \mathrm{B}$ levels mediate the resistance of clonal neuronal cells against oxidative stress (Lezoualc'h et al., 1998b) and may therefore drive the transcription of neuroprotective genes, a view that has been suggested previously (Barger and Mattson, 1996). We conclude that depending on the experimental and cellular paradigm and on the mode and kinetics of activation (consistently increased vs immediately increased by oxidative neurotoxins), $\mathrm{NF}-\kappa \mathrm{B}$ may exert multiple functions with respect to neuronal cell survival.

Vitamin E is a lipophilic free radical scavenger that protects neuronal cells against HP toxicity (Behl et al., 1996) because it interacts with cell membranes, traps free radicals, and interrupts the oxidative redox chain reaction that damages cells (Halliwell and Gutteridge, 1989; Halliwell, 1992). Tissue damage and cell death caused by lipid peroxidation can be prevented by vitamin $\mathrm{E}$ 


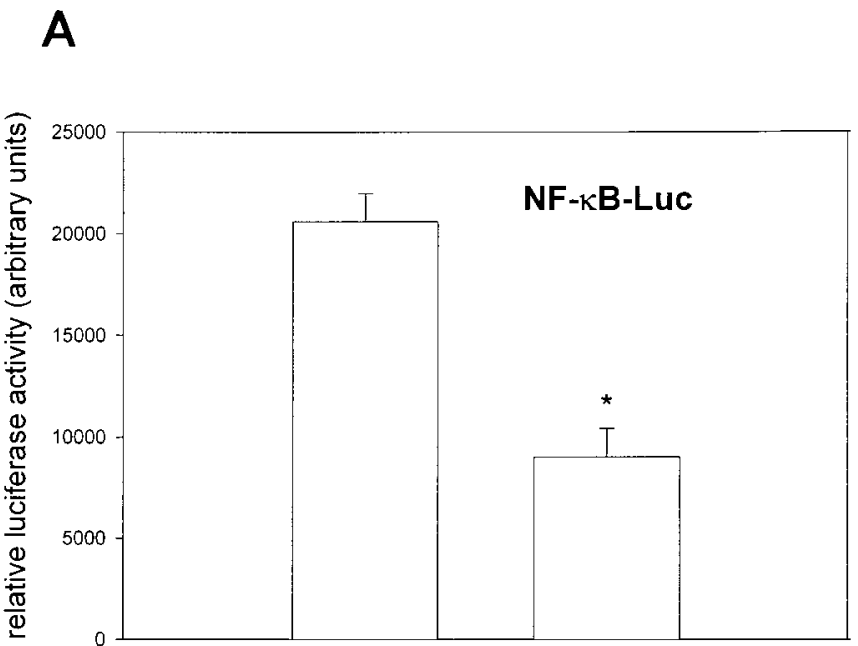

CT-vector $\quad \mathrm{I} \mathrm{B} \mathrm{B} \alpha$ super-repressor

B

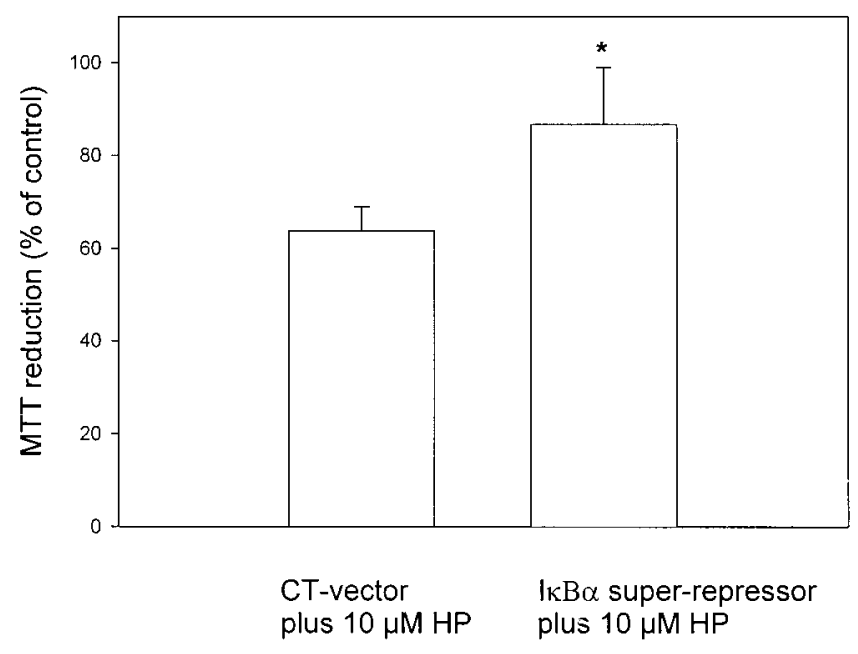

Figure 7. Overexpression of $\mathrm{I} \kappa \mathrm{B} \alpha$ super-repressor suppresses the baseline activity of NF- $\kappa \mathrm{B}$ in HT22 cells compared with control-transfected cells $(A)$. Cells were cotransfected with $\mathrm{CMV}-\mathrm{I} \kappa \mathrm{B} \alpha$ super-repressor and $6 \times \mathrm{NF}-\kappa \mathrm{B}$-tk-Luc vector or with the CMV-control-vector missing the $\mathrm{I} \kappa \mathrm{B} \alpha$ cDNA (CT-vector) and $6 \times \mathrm{NF}-\kappa \mathrm{B}-\mathrm{tk}-\mathrm{Luc}$ vector. Baseline transcriptional activity of NF- $\kappa \mathrm{B}$ is shown in $A$. In $B$, cells were transfected with $\mathrm{CMV}-\mathrm{I} \kappa \mathrm{B} \alpha$ super-repressor or the $\mathrm{CMV}$-control vector. The cell viability as assessed by the MTT reduction is shown after $10 \mu \mathrm{M} \mathrm{HP}$ challenge for $2 \mathrm{hr} .{ }^{*} p<0.01$ versus the control-transfected conditions.

such as in cultured hypoxic neurons (Yoshida et al., 1985; Lohr et al., 1988), but possible molecular mechanisms underlying vitamin E-mediated resistance of neurons to oxidative stress are not fully understood. In our study, melatonin, $N$-acetyl-serotonin, and vitamin E protected HT22 cells with varying efficiency against HP toxicity. Overall, vitamin E proved to be most efficient in protecting HT22 cells. Vitamin E and $N$-acetyl-serotonin have structural similarities: both molecules have a phenolic group that could provide a proton to detoxify hydroxyl radicals or lipid radicals (Halliwell and Gutteridge, 1989). Recently, we reported that a phenolic hydroxyl group in the aromatic ring $\mathrm{A}$ is the prerequisite of a neuroprotective effect of estrogens against oxidative chal- lenges (Behl et al., 1997). In the present study, the aromatic alcohol $N$-acetyl-serotonin showed a higher protective potential compared with melatonin against HP toxicity, consistent with our recent observations (Moosmann et al., 1997).

The generation of peroxides was blocked by vitamin $\mathrm{E}$ and $N$-acetyl-serotonin. In contrast, melatonin was not able to reduce peroxide accumulation significantly. Furthermore, vitamin E consistently stabilized the intracellular GSH content most effectively. Analogous to the conclusions drawn by Grilli et al. (1996), we assume that the decrease in NF- $\kappa$ B's transcriptional activity and in its DNA binding activity by $N$-acetyl-serotonin and vitamin $\mathrm{E}$ is causally related to their neuroprotective effect. These neuroprotective antioxidants might therefore be able to suppress the $\mathrm{NF}-\kappa \mathrm{B}$-driven gene transcription as a part of HP-induced neuronal cell death. This was further confirmed by the fact that the transient suppression of NF- $\kappa$ B's activity by overexpression of a $\mathrm{I} \kappa \mathrm{B} \alpha$ super-repressor partially prevented HP toxicity in HT22 cells. Further studies will focus on possible target genes of HPinduced increased NF- $\kappa$ B activity.

In conclusion, we here present evidence that the neuroleptic drug HP causes oxidative stress via the induction of intracellular peroxide accumulation followed by the depletion of intracellular GSH in clonal hippocampal HT22 cells. At the molecular level, $\mathrm{HP}$ induces the activity of NF- $\kappa \mathrm{B}$ and ultimately causes neuronal cell death that can be prevented by vitamin $\mathrm{E}$ and $N$-acetylserotonin and to a lesser degree by melatonin. With respect to the involved mechanism, we propose that these antioxidants may have a dual mode of action. (1) They block the immediate rise in peroxides and the subsequent lipid peroxidation, and (2) they suppress the HP-induced activation of NF- $\kappa \mathrm{B}$. Regarding the possible clinical implications of the present findings, it is of note that therapeutic plasma HP concentrations are $\sim 0.05 \mu \mathrm{M}$ (Baldessarini et al., 1988; Van Putten, 1991) and therefore lower than the HP concentrations used in the present in vitro study. However, plasma concentrations do not necessarily reflect local cerebral concentrations. Thus high HP levels at specific target sites are possible. They may trigger oxidative stress in neuronal cells, resulting in long-lasting potentially irreversible damage, which among other clinical symptoms may lead to tardive dyskinesia in vulnerable patients. Such untoward clinical conditions could potentially be prevented by coadministration of antioxidants such as vitamin E.

\section{REFERENCES}

Bains JS, Shaw CA (1997) Neurodegenerative disorders in humans: the role of glutathione in oxidative stress-mediated neuronal cell death. Brain Res Rev 25:335-358.

Baldessarini RJ, Cohen BM, Teicher MH (1988) Significance level of neuroleptic dose and plasma level in the pharmacological treatment of psychoses. Arch Gen Psychiatry 45:79-91.

Baldwin AS (1996) The NF- $\kappa \mathrm{B}$ and $\mathrm{I} \kappa \mathrm{B}$ proteins: new discoveries and insight. Annu Rev Immunol 14:649-668.

Barger SW, Mattson MP (1996) Induction of neuroprotective $\kappa \mathrm{B}$ dependent transcription by secreted forms of the Alzheimer's $\beta$-amyloid precursor. Mol Brain Res 40:116-126.

Bäuerle P, Henkel T (1994) Function and activation of NF- $\kappa$ B in the immune system. Annu Rev Immunol 12:141-179.

Behl C, Davis JB, Lesley, Schubert D (1994) Hydrogen peroxide mediates amyloid $\beta$ protein toxicity. Cell 77:817-827.

Behl C, Rupprecht R, Skutella T, Holsboer F (1995) Haloperidolinduced cell death-mechanism and protection with vitamin $\mathrm{E}$ in vitro. NeuroReport 7:360-364.

Behl C, Lezoualc'h F, Widmann M, Rupprecht F, Holsboer F (1996) 
Oxidative stress-resistant cells are protected against haloperidol toxicity. Brain Res 717:193-195.

Behl C, Skutella T, Lezoualc'h F, Post A, Widmann M, Newton CJ, Holsboer F (1997) Neuroprotection against oxidative stress by estrogens: structure-activity relationship. Mol Pharmacol 51:535-541.

Boussif O, Lezoualc'h F, Zanta MA, Mergny MD, Scherman D, Demeneix B, Behr JP (1995) A versatile vector for gene and oligonucleotide transfer into cells in culture and in vivo: polyethyleninime. Proc Natl Acad Sci USA 92:7297-7301.

Bowen WD, Moses EL, Tolentino PJ, Walker M (1990) Metabolites of haloperidol display preferential activity at $\sigma$ receptors compared to dopamine-D2 receptors. Eur J Pharmacol 177:111-118.

Brennan P, O’Neill LAJ (1995) Effects of oxidants and antioxidants on nuclear factor $\kappa \mathrm{B}$ activation in three different cell lines: evidence against a universal hypothesis involving oxygen radicals. Biochim Biophys Acta 1260:167-175.

Brockman JA, Scherer DC, McKinsey TA, Hall SM, Qi XX, Lee WY, Ballard DW (1995) Coupling of a signal response domain in $\mathrm{I} \kappa \mathrm{B} \alpha$ to multiple pathways for NF- $\kappa \mathrm{B}$ activation. Mol Cell Biol 15:2809-2818.

Cadet JL, Lohr JB, Jeste DV (1986) Free radicals and tardive dyskinesia. Trends Neurosci 3:107-108.

Coyle JT, Puttfarcken P (1993) Oxidative stress, glutamate, and neurodegenerative disorders. Science 262:689-695.

Creese I, Burt D, Snyder SH (1976) Dopamine receptor binding predicts clinical and pharmacological potencies of antischizophrenic drugs. Science 192:481-483.

De Wet JR, Wood KV, DeLuca M, Helsinki DR, Subramani S (1987) Firefly luciferase gene: structure and expression in mammalian cells. Mol Cell Biol 7:725-737.

Dröge W, Schulze-Osthoff K, Mihm S, Galter D, Schenk H, Eck HP, Roth S, Gmünder H (1995) Functions of glutathione and glutathione disulfide in immunology and immunopathology. FASEB J 8:1131-1138.

Egan MF, Hyde TM, Albers GW, Elkashef A, Alexander RC, Reeve A, Blum A, Saenz RE, Wyatt RJ (1992) Treatment of tardive dyskinesia with vitamin E. Am J Psychiatry 149:773-777.

Ginn-Pease ME, Whisler RL (1996) Optimal NF-kB mediated transcriptional responses in Jurkat $\mathrm{T}$ cells exposed to oxidative stress are dependent on intracellular glutathione and costimulatory signals. Biochem Biophys Res Commun 226:695-702.

Griffith O (1980) Determination of glutathione and glutathione disulfide using glutathione reductase and 2-vinylpyridine. Anal Biochem 106:207-221.

Grilli M, Chiu JS, Lenardo M (1993) NF- $\kappa$ B and Rel: participation in a multiform transcriptional regulatory system. Int Rev Cytol 143:1-62.

Grilli M, Pizzi M, Memo M, Spano P (1996) Neuroprotection by aspirin and sodium salicylate through blockade of NF- $\kappa \mathrm{B}$ activation. Science 274:1383-1385.

Halliwell B (1992) Reactive oxygen species and the central nervous system. J Neurochem 59:1609-1622.

Halliwell B, Gutteridge JMC (1989) Free radicals in biology and medicine. Oxford, UK: Oxford UP.

Kaltschmidt B, Uherek M, Volk B, Baeuerle PA, Kaltschmidt C (1997) Transcription factor $\mathrm{NF}-\kappa \mathrm{B}$ is activated in primary neurons by amyloid beta peptides and in neurons surrounding early plaques from patients with Alzheimer disease. Proc Natl Acad Sci USA 94:2642-2647.

Lezoualc'h F, Behl C (1998) Transcription factor NF- $\kappa$ B: friend or foe of neurons? Mol Psychiatry 3:15-20.

Lezoualc'h F, Skutella T, Widman M, Behl C (1996) Melatonin prevents oxidative stress-induced cell death in hippocampal cells. NeuroReport 7:2071-2077.

Lezoualc'h F, Sparapani M, Behl C (1998a) N-acetyl-serotonin (normelatonin) and melatonin protect neurons against oxidative challenge and suppress the activity of the transcription factor NF- $\kappa$ B. J Pineal Res $24: 168-178$.

Lezoualc'h F, Sagara Y, Holsboer F, Behl C (1998b) High constitutive $\mathrm{NF}-\kappa \mathrm{B}$ activity mediates resistance to oxidative stress in neuronal cells. J Neurosci 18:3224-3232.

Li Y, Maher P, Schubert D (1997) A role for 12-lipooxygenase in nerve cell death caused by glutathione depletion. Neuron 19:453-463.

Lipton SA (1997) Janus faces of NF- $\kappa$ B: Neurodestruction versus neuroprotection. Nat Med 3:20-22.

Liu Y, Peterson DA, Kimura H, Schubert D (1997) Mechanism of cellular 3-(4,5-dimethylthiazol-2yl)-2,5 diphenyltetrazolium bromide (MTT) reduction. J Neurochem 69:581-593.

Lohr JB, Caligiuri MP (1996) A double blind placebo-controlled study of vitamin $\mathrm{E}$ treatment of tardive dyskinesia. J Clin Psychiatry 57:167-173.

Lohr JB, Cadet JL, Lohr MA, Larson L, Wasli E, Wade L, Hylton R, Vidoni C, Jeste DV, Wyatt RJ (1988) Vitamin E in the treatment of tardive dyskinesia: the possible involvement of free radical mechanism. Schizophr Bull 14:291-296.

Maher P, Davis J (1996) The role of monoamine metabolism in oxidative glutamate toxicity. J Neurosci 15:6394-6401.

Marsden CD, Jenner P (1980) The pathophysiology of extrapyramidal side-effects of neuroleptic drugs. Psychol Med 10:55-72.

Martensson J, Jain A, Frayer W, Meister A (1989) Glutathione metabolism in the lung: inhibition of its synthesis leads to lamellar body mitochondrial defects. Proc Natl Acad Sci USA 86:5296-5300.

Meister A (1991) Glutathione deficiency produced by inhibition of its synthesis, and its reversal; applications in research and therapy. Pharmacol Ther 51:155-194.

Melchiorri D, Reiter R, Attia AM, Hara M, Burgos A, Nistico G (1995) Potent protective effect of melatonin on in vivo paraquat-induced oxidative damage in rats. Life Sci 56:83-89.

Meyer M, Schreck R, Bäuerle PA (1993) $\mathrm{H}_{2} \mathrm{O}_{2}$ and antioxidants have opposite effects on activation of $\mathrm{NF}-\kappa \mathrm{B}$ and AP-1 in intact cells: AP-1 as secondary antioxidant-responsive factor. EMBO J 12:2005-2015.

Mihm S, Galter D, Dröge W (1995) Modulation of transcription factor NF- $\kappa \mathrm{B}$ activity by intracellular glutathione levels and by variations of the extracellular cysteine supply. FASEB J 9:246-252.

Moosmann B, Uhr M, Behl C (1997) Neuroprotective potential of aromatic alcohols against oxidative cell death. FEBS Lett 413:467-472

Olanow CW (1992) An introduction to the free radical hypothesis in Parkinson's disease. Ann Neurol 32:S2-S9.

Olanow CW (1993) A radical hypothesis for neurodegeneration. Trends Neurosci 16:439-444.

Pai BN, Janakiramaiah N, Gangadhar BN, Ravindranath V (1994) Depletion of glutathione and enhanced lipid peroxidation in the CSF of acute psychotics following haloperidol administration. Biol Psychiatry 36:489-491.

Papolla MA, Sos M, Omar RA, Bick RJ, Hicksonbick DLM, Reiter RJ, Efthimiopoulos S, Robakis NK (1997) Melatonin prevents death of neuroblastoma cells exposed to the Alzheimer amyloid protein. J Neurosci 17:1683-1690.

Pinkus R, Weiner LM, Daniel V (1996) Role of oxidants and antioxidants in the induction of AP-1, NF- $\kappa \mathrm{B}$, and glutathione S-transferase gene expression. J Biol Chem 23:13422-13429.

Reiter RJ, Oh CS, Fujimori O (1996) Melatonin its intracellular and genomic actions. Trends Endocrinol Metab 7:22-26.

Schenk H, Klein M, Erdbrügger W, Dröge W, Schulze-Osthoff K (1994) Distinct effects of thioredoxin and antioxidants on the activation of transcription factors NF- $\kappa \mathrm{B}$ and AP-1. Proc Natl Acad Sci USA 91:1672-1676.

Schieven GL, Mittler RS, Nadler SG, Kirihara JM, Bolen JB, Kanner SB, Ledbetter JA (1994) Zap-70 tyrosine kinase, CD45, and T cell receptor involvement in $\mathrm{UV}$ - and $\mathrm{H}_{2} \mathrm{O}_{2}$-induced $\mathrm{T}$ cell signal transduction. J Biol Chem 269:20718-20726.

Schmidt KN, Amstad P, Cerutti P, Bäuerle PA (1995) The roles of hydrogen peroxide and superoxide as messengers in the activation of transcription factor NF- $\kappa$ B. Chem Biol 2:13-22.

Schreck R, Zorbas H, Winnacker EL, Bäuerle PA (1991) Reactive oxygen intermediates as apparently widely used messengers in the activation of the NF- $\kappa$ B transcription factor and HIV-1. EMBO J 10:2247-2258.

Schreiber E, Matthias P, Müller MM, Schaffner W (1989) Rapid detection of octamer binding proteins with mini-extracts, prepared from a small number of cells. Nucleic Acids Res 17:6419.

Sen R, Baltimore D (1986) Multiple nuclear factors interact with the immunoglobulin enhancer sequences. Cell 46:705-706.

Shivakumar BR, Ravindranath V (1992) Oxidative stress induced by administration of the neuroleptic drug haloperidol is attenuated by higher doses of haloperidol. Brain Res 595:256-262.

Shivakumar BR, Ravindranath V (1993) Oxidative stress and thiol modification induced by chronic administration of haloperidol. J Pharmacol Exp Ther 3:1137-1141.

Staal FJT, Anderson MT, Staal GEJ, Herzenberg LA, Gitler C, Herzenberg LA (1994) Redox regulation of signal transduction: tyrosine phosphorylation and calcium influx. Proc Natl Acad Sci USA 91:3619-3622. 
Tietze F (1969) Enzymatic method for quantitative determination of nanogram amounts of total and oxidized glutathione: applications to mammalian blood and other tissues. Anal Biochem 27:502-522.

Van Putten T, Marder SR, Wirshing WC, Aravagiri M, Chabert N (1991) Neuroleptic plasma levels. Schizophrenia Bull 17:197-216.

Vilner BJ, Bowen WD (1993) $\sigma$-receptor active neuroleptics are cytotoxic to C6 glioma cells in culture. Eur J Pharmacol 244:199-201.

Vilner BJ, Costa BR, Bowen WD (1995) Cytotoxic effects of $\sigma$ ligands: $\sigma$ receptor-mediated alterations in cellular morphology and viability. J Neurosci 15:117-134.

Walker JM, Bowen WD, Walker FO, Matsumoto RR, De Costa B, Rice CK (1990) Sigma receptors: biology and function. Pharmacol Rev 42:355-402.

Yoshida S, Busto R, Watson BD, Santiso M, Ginsberg MD (1985) Postischemic cerebral lipid peroxidation in vitro: modification by dietary vitamin E. J Neurochem 44:1593-1601. 